\title{
Bee-flower association in the Neotropics: implications to bee conservation and plant pollination
}

\author{
Alípio José de Souza PACHECO FILHO ${ }^{1}$, Christiano Franco Verola ${ }^{1}$, \\ Luiz Wilson Lima VERDE ${ }^{1}$, Breno Magalhães Freitas ${ }^{2}$ \\ ${ }^{1}$ Departamento de Biologia, Universidade Federal do Ceará, Fortaleza 60.440-900 Ceará, Brazil \\ ${ }^{2}$ Departamento de Zootecnia, Universidade Federal do Ceará, Fortaleza 60.356-000 Ceará, Brazil
}

Received 24 February 2014 - Revised 17 November 2014 - Accepted 9 December 2014

\begin{abstract}
There is a growing interest in bee conservation given their importance for the maintenance of biodiversity and food production. However, little is known about most bee species and their associated flora, particularly in the Neotropics. In this study, based on raw data published and own data, we presented the most important plant families for the maintenance of the tribes and functional groups of bees across different Brazilian ecoregions. We also present the close relationship of tribes composed by oligolectic bees and their associated plant families. In addition, we identified the most generalist bees of these ecoregions since they could be important to maintain community stability.
\end{abstract}

specialization / generalization / Atlantic Forest / Caatinga / Cerrado

\section{INTRODUCTION}

Relationships between bees and plants can be mutually beneficial. Bees seek flowers mainly to search for food to sustain themselves and their offspring, and during this process, they may promote the deposition of conspecific pollen on the stigma of the visited flower (Faegri and van der Pijl 1979). These mutually beneficial relationships have been considered the main factor in the evolution of angiosperms and bees (Cardinal and Danforth 2013) and are responsible for global food production, which human persistence depends upon (Garibaldi et al. 2013).

Electronic supplementary material The online version of this article (doi:10.1007/s13592-014-0344-8) contains supplementary material, which is available to authorized users.

Corresponding author: A. PACHECO FILHO, alipiopachecofilho@hotmail.com Handling Editor: Yves le Conte
Given such importance of bees, a growing concern about the conservation of bee species has become prominent in both scientific circles as in politics (Spivak et al. 2011). For any effort for bee conservation, it becomes necessary to know the occurring species and the resources they use. Despite this, little is known about most groups of bees and their associated flora, especially in Neotropical regions (Freitas et al. 2009; Pinheiro-Machado et al. 2002). In general, it has been suggested that relationships between bees and plants are generalist, with bees (or plants) interacting with various plants (or bees) (Waser et al. 1996). According to the current theoretical framework, such generalist species are important to maintain the cohesion and stability of plant-bee networks (Memmott et al. 2004). On the other hand, relationships between plants and bees may exhibit phylogenetic components that drive the preferences of a group of bees to a given group of plants (Müller 1996; Patiny et al. 2008). Thus, certain bee taxa preferentially visit certain plant families or genera. This relationship can be so 
close that the development of the offspring of a bee may be related to the botanical origin of the resource used (Carvalho and Schlindwein 2011).

Some bees have developed convergent characteristics specialized in the exploitation of floral resources, forming functional groups (Fenster et al. 2004). Thus, nectar from flowers with long tubes can only be really accessed by long-tongued bees, regardless of species identity. Similarly, pollen inside poricidal anthers can only be collected really legitimately by bees that vibrate. Therefore, the bee-plant relationships may also have functional components that drive the preferences of a group of bees to a particular group of plants (Schlindwein 2004a).

In this work, based on raw data published and own data, we are interested in knowing whether there are preferential associations between certain tribes and functional groups of bees and plants and whether these are maintained across different Brazilian ecoregions. We are also interested in identifying the most generalist bees (i.e., those interacting with the highest number of plant species) occurring in these ecoregions since they could be important to maintain community stability (Memmott et al. 2004). This information may be relevant to the conservation of bee species since the understanding of bee communities and their association with the flora of certain habitats may be a useful tool to identify the vulnerability of these organisms to changes in the landscape.

\section{MATERIALS AND METHODS}

\subsection{Biomes and ecoregions}

This study was carried out in some Brazilian biomes and ecoregions, the largest country in the Neotropics. We collected raw data from articles, theses, and data of the authors (see Online Resource 1) that were classified into three ecoregions belonging to three biomes according to the World Wildlife Fund (WWF) (Olson et al. 2001). This classification was selected due to the conservation purposes of the present study and because ecoregions reflect more accurately the distribution of species and communities than units based on global and regional models derived from purely biophysical characteristics (Olson et al. 2001).
The biome tropical and subtropical moist broadleaf forest analyzed herein corresponds to the Atlantic Forest for including the ecoregions of moist forest enclaves in the Caatinga, forests of Pernambuco, and Araucaria forest (sensu WWF Brazil 2014). The second biome (tropical and subtropical grasslands, savannas, and shrublands) has a unique ecoregion, the Cerrado. It was decided to consider a community from the ecoregion of the Maranhão Babaçu Forest as Cerrado because it shows physiognomy and species composition typical of this savanna and absence of species typical of the Babassu Forest (e.g., Attalea speciosa Mart. ex Spreng.--babassu, Copernicia prunifera (Mill.) H.E. Moore and Mauritia flexuosa L. f.). The third biome (Deserts and Xeric Shrublands) has only the Caatinga ecoregion (Online Resource 1).

The Atlantic Forest (a complex of ecoregions hereinafter referred to as an ecoregion) analyzed herein includes the Atlantic Rainforest and the Semideciduous Atlantic Forest, which are mainly composed of macroand mesophanerophytes. It has high moisture due to the slope rainfall $(>1,000 \mathrm{~mm})$ caused by the mountains that block the movement of clouds. This moisture can be favored by humid winds coming from the ocean (Oliveira-Filho and Fontes 2000). The Cerrado is conceptualized as a xerophytic vegetation occurring in different climatic types. In general, its flora is adapted to fire. It has aluminum leached soils, presenting synusiae of hemicryptophytes, geophytes, camephytes, and small-sized oligotrophic phanerophytes (Oliveira-Filho and Ratter 2002; Brasil 2012). The Caatinga is characterized as a tree or shrub vegetation, including mainly low shrubs and trees, many of which have spines, microphylia, and some xerophytic characteristics (Prado 2003). The climate is characterized by strong seasonality and plants usually lose their leaves in the dry season (Rizzini 1997).

\subsection{Data collection}

We analyzed dozens of published studies (articles, doctoral theses) to search for raw data on bee-plant interactions at the community level. With selected studies $(n=15)$ added to our own data $(n=4)$, we elaborated 19 bee-plant networks from three Brazilian ecoregions (Atlantic Forest: $n=8$; Cerrado: $n=7$, and Caatinga: $n=4)$. All the works followed the collection method similar to that proposed by Sakagami et al. (1967). Only bees collected on flowers were considered. The studies 
were developed for at least 12 months (12-27 months) and exhibited different sampling effort (72-1,620 h). The works encompassed the whole annual phenological cycle of the studied plant species and their visitors. Therefore, we considered that they were representative of the flora and bee species of each site. Only one selected study was not performed for 12 consecutive months, but we use it because of the scarcity of data for the Caatinga. The sampling effort and species richness of that study was similar to other studies selected for Caatinga (Online Resource 1). We followed the Nomenclatural Data Base of the Missouri Botanical Garden (www.tropicos.org) and Michener (2007) to classify the bee species into their taxa.

\subsection{Tribes and functional groups of bees and plant families}

First, we grouped the species of bees into tribes. As there is little information available on the biology of many species recorded in our data set, we used the characteristics of the tribes to classify the bees into functional groups according to the resource used or collected in flowers. The functional groups formed were the following: (i) long-tongued bees, (ii) short-tongued bees, (iii) bees that vibrate to collect pollen, (iv) floral oil-collecting bees, (v) scent-collecting bees, and (vi) resin-collecting bees. We also assessed whether the tribes were composed by oligolectic bees (sensu Robertson (1925)) using information by Schlindwein (2004a, b) for Brazilian bees (Table I). Plants were grouped into families. The family Fabaceae was divided into three subfamilies (Caesalpinioideae, Mimosoideae, and Papilionoideae) due to the large differences in floral morphology within this family.

\subsection{Data analysis}

\subsubsection{Number of species of bees per tribe}

We identified tribes of bees with greater richness by computing the number of species per tribe for each community. Then, the total number of bees of a given tribe was divided by the number of sampled communities within an ecoregion, obtaining thus the average richness of each tribe per ecoregion. We identified the most species-rich families of plants in an analogous manner.

\subsubsection{Importance of plant families for tribes and functional groups of bees}

We were interested in identifying the importance of each plant family as a resource for bees. As a single species can be classified into more than one functional group (e.g., Euglossini bees have long tongue, vibrate, and collect resin), we did not perform this analysis for functional groups, as this would bring noise to the analysis. Therefore, we identified the importance of a botanical family for each tribe of bees by identifying which plant species are visited by bees of a given tribe. The proportion of plant species of each plant family interacting with a given bee tribe in relation to the total of plants that bees of that tribe visit was also calculated. The following formula was used: $\mathrm{Pij}=\mathrm{Nij} / \mathrm{Ni}$, where $\mathrm{Nij}$ is the number of species that the botanical family $j$ provides for the bee tribe $i, \mathrm{Ni}$ is the total number of plant species interacting with the tribe $i$ of Apoidea and Pij is the importance of the botanical family $j$ for the tribe $i$ of Apoidea. Based on this analysis, we separated the tribes of bees into functional groups and tried to identify the most important families for each group within each ecoregion. We also analyzed whether a relationship exists between the number of species of bees belonging to a functional group and the number of plant species associated. These analyses were run only for oil-collecting bees and bees that vibrate due to lack of data on other functional groups.

\subsubsection{Generalist bee species}

The more generalist bee species were identified to all 19 networks studied. As a surrogate to the level of bee generalism, we used the metric named "relative degree" (Bascompte et al. 2006). The relative degree is the proportion of interactions of a species in relation to the number of interactions it could have done, considering that a bee could, potentially, interact with any plant. Therefore, the higher the relative degree, the more generalist is the bee species. Then, we selected the five species with the highest relative degree of each community and calculated the average relative degree for each of the selected species. For this, we divided the sum of the relative degrees of one species by the number of selected communities in each ecoregion. For eusocial bees of the tribe Meliponini, we investigated whether the level of generalism is related to population size. We 
Table I. Families and tribes of bees registered in the set of raw data and their morphological and behavioral characteristics.

\begin{tabular}{|c|c|c|c|c|c|c|}
\hline \multirow[t]{2}{*}{ Family/tribe } & \multirow[t]{2}{*}{ Tongue $^{\mathrm{a}}$} & \multicolumn{3}{|c|}{ Collection of ${ }^{b}$} & \multirow[t]{2}{*}{ Pollen collection by vibration ${ }^{b}$} & \multirow[t]{2}{*}{ Oligolecty $^{\mathrm{b}}$} \\
\hline & & Oil & Scent & Resin & & \\
\hline Andrenidae & Short & & & & & \\
\hline Calliopsini & & & & & & $\times$ \\
\hline Oxaeini & & & & & $x$ & \\
\hline Protandrenini & & & & & & $\times$ \\
\hline Protomeliturgini & & & & & & $x$ \\
\hline Apidae & Long & & & & & \\
\hline \multicolumn{7}{|l|}{ Apini } \\
\hline \multicolumn{7}{|l|}{ Bachynomadini } \\
\hline Bombini & & & & & $x$ & \\
\hline Centridini & & $x$ & & & $x$ & $x^{c}$ \\
\hline \multicolumn{7}{|l|}{ Ceratinini } \\
\hline Emphorini & & & & & & $x$ \\
\hline \multicolumn{7}{|l|}{ Epeolini } \\
\hline \multicolumn{7}{|l|}{ Ericrocidini } \\
\hline Eucerini & & & & & $\times$ & $\times$ \\
\hline Euglossini & & & $x$ & $x$ & $x$ & \\
\hline Exomalopsini & & & & & $x$ & \\
\hline Meliponini & & & & $x$ & $x^{c}$ & \\
\hline \multicolumn{7}{|l|}{ Nomadini } \\
\hline \multicolumn{7}{|l|}{ Osirini } \\
\hline \multicolumn{7}{|l|}{ Protepeolini } \\
\hline \multicolumn{7}{|l|}{ Rhathymini } \\
\hline Tapinotaspidini & & $x$ & & & & $x^{\mathrm{c}}$ \\
\hline Tetrapediini & & $x$ & & & & $?$ \\
\hline Xylocopini & & & & & $x$ & \\
\hline Colletidae & Short & & & & & \\
\hline Colletini & & & & & $x$ & $?$ \\
\hline Diphaglossini & & & & & $x$ & \\
\hline Hylaeini & & & & & & $?$ \\
\hline Paracolletini & & & & & & $x$ \\
\hline Xeromelissinae $^{\mathrm{d}}$ & & & & & $x$ & $?$ \\
\hline Halictidae & Short & & & & & \\
\hline Augochlorini & & & & & $x$ & $?$ \\
\hline Halictini & & & & & $x$ & $x^{\mathrm{c}}$ \\
\hline Rophitini & & & & & & $x$ \\
\hline Megachilidae & Long & & & & & \\
\hline
\end{tabular}


Table I (continued)

\begin{tabular}{|c|c|c|c|c|c|c|}
\hline \multirow[t]{2}{*}{ Family/tribe } & \multirow[t]{2}{*}{ Tongue $^{\mathrm{a}}$} & \multicolumn{3}{|c|}{ Collection of $^{b}$} & \multirow[t]{2}{*}{ Pollen collection by vibration ${ }^{b}$} & \multirow[t]{2}{*}{ Oligolecty $^{b}$} \\
\hline & & Oil & Scent & Resin & & \\
\hline Anthidini & & & & $x$ & & $x^{c}$ \\
\hline Lithurgini & & & & & & $\times$ \\
\hline Megachilini & & & & & & $x$ \\
\hline
\end{tabular}

${ }^{\text {a }}$ Michener (2007)

${ }^{\mathrm{b}}$ Schlindwein (2004a, b)

${ }^{\mathrm{c}}$ Some species

${ }^{\mathrm{d}}$ Subfamily

used the number of bees collected on flowers as a substitute of population size.

\subsection{Statistical analysis}

The relationship between the number of species of bees that vibrate with the number of plant species with poricidal anthers was tested by Pearson correlation $(R)$. Additionally, we used the Spearman correlation (Rs) to investigate the relationship between the number of species of oil-collecting bees with the number of species of oil-flower plants and between the levels of generalism with population size of Meliponini species.

\section{RESULTS}

\subsection{Tribes of bees and families of plants}

Centridini, Meliponini, Augochlorini, and Megachilini were the most species-rich tribes in the ecoregions studied (Figure 1). Except for Megachilini, these groups and Apini (mainly Meliponini and Apini) were the tribes that interacted with the largest number of plant families across the ecoregions (Figure 2). In the Cerrado, there was a higher number of species of oil-collecting bees (Tapinotaspidini, Tetrapedini, and Centridini) (Figure 1). In this ecoregion, Tapinotaspidini also stood out with large numbers of partner plant families. The tribe Ceratinini showed a higher number of partner families in the Atlantic Forest and Cerrado, whilst the tribe Xylocopini showed a higher number of partner families in the Caatinga. Both tribes were related mainly to the species-richest families.
Some botanical families were remarkably representative in the total of plants used by tribes formed by oligolectic bees (Table I). Megachilini bees visited more species of Asteraceae, even in the Caatinga, where this plant family was less expressive (number of Asteraceae species: Cerrado $=39$, Atlantic Forest $=67$, and Caatinga $=6$ ) (Figure 2). Likewise, Emphorini interacted with more species of Convolvulaceae (Figure 2). Furthermore, the interactions of oligolectic bees of the tribe Protomelithurgini with Passifloraceae (including Turneraceae), of Paracolletini with Malvaceae and Eucerini with Malvaceae and with Asteraceae remained in the different ecoregions (Figure 2).

\subsection{Functional groups}

There was no clear distinction between the botanical families used by short- and longtongued bees. In general, members of both groups visited plants of families most represented of each ecoregion (Figure 3). Although the families of plants with poricidal anthers (e.g., Solanaceae, Melastomataceae, and Ochnaceae) have not been among those that provided the largest number of species for bees that collect pollen by vibration (Figure 2), we found a positive relationship between the number of plant species with poricidal anthers and the number of species of bees that vibrate $(R=0.66, P=0.002$, Figure $4 \mathrm{a})$.

Floral oil-collecting bees (especially Centridini) have commonly visited plants with oil-flowers across the three ecoregions. However, this relationship was more prominent in the 


\section{Cerrado}

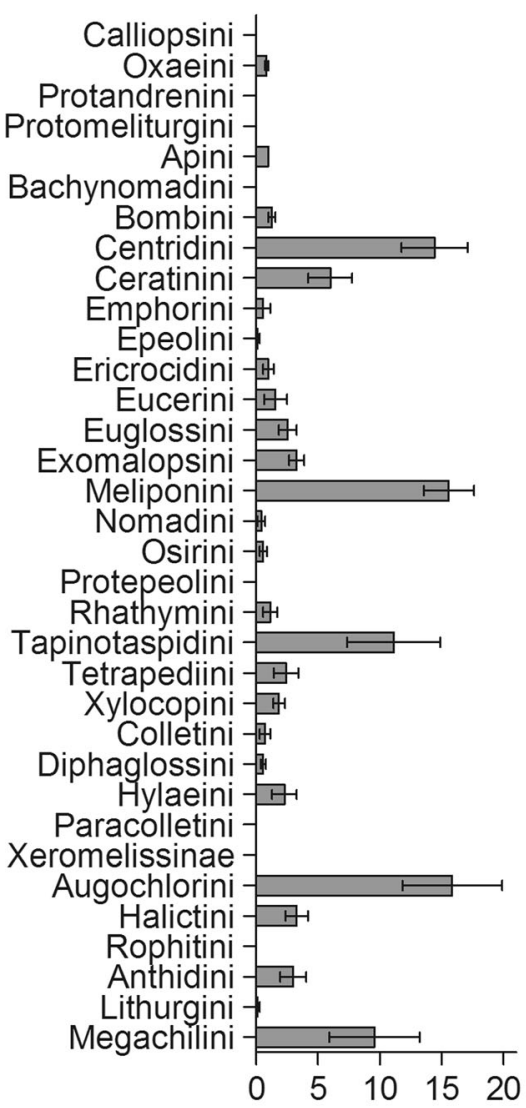

Atlantic Forest

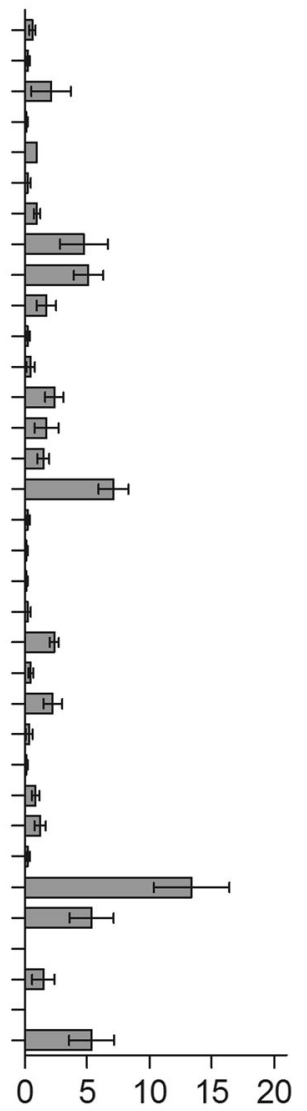

Caatinga

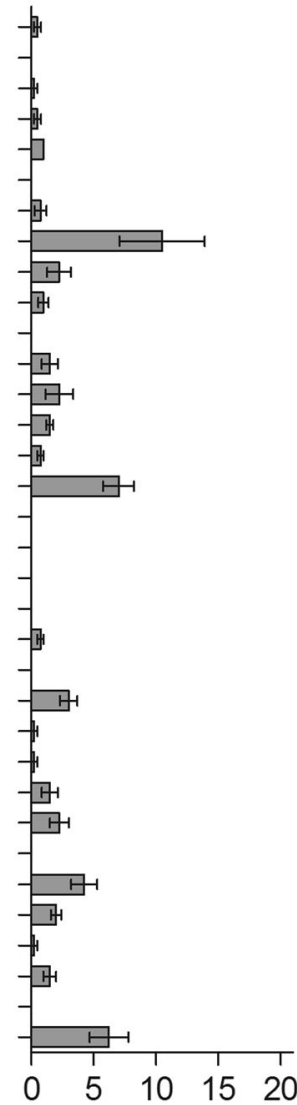

Mean number of bee species per tribe

Figure 1. Mean number of species of bees per tribe for each ecoregion.

Cerrado (Figure 2). We found that the higher the species richness of oil-flower plants, the greater the number of species that collect oil $(\mathrm{Rs}=0.67$, $P=0.001$, Figure $4 \mathrm{~b}$ ). We registered interactions between floral scent-collecting bees (Euglossini males) and plants that have floral scents (Solanaceae), only in the Atlantic Forest (Figure 2). Species with resin-producing flowers (e.g. Dalechampia L. spp. and Clusia L. spp.) were not registered in our dataset.

\subsection{Generalist bee species}

Apis mellifera Linnaeus and Trigona spinipes Fabricius were the most generalist species in all ecoregions (Figure 5a-c). Among the most generalist species, only Dialictus opacus Moure
(Halictidae) does not belong to Apidae and only Xylocopa grisescens Lepeletier is parasocial (Figure 5c). The remaining are highly eusocial apids having colonies of hundreds of foragers. Most generalist bee species found belong to the Meliponini. For this tribe, the generalism level was highly correlated with the number of individuals collected in the flowers $(\mathrm{Rs}=0.88, P<0.0001$, Figure 4c).

\section{DISCUSSION}

The tribes Meliponini and Apini consists of eusocial bees that commonly form perennial colonies with large numbers of workers (Michener 2007). This requires a large amount of resources collected throughout the year, favoring the use of 


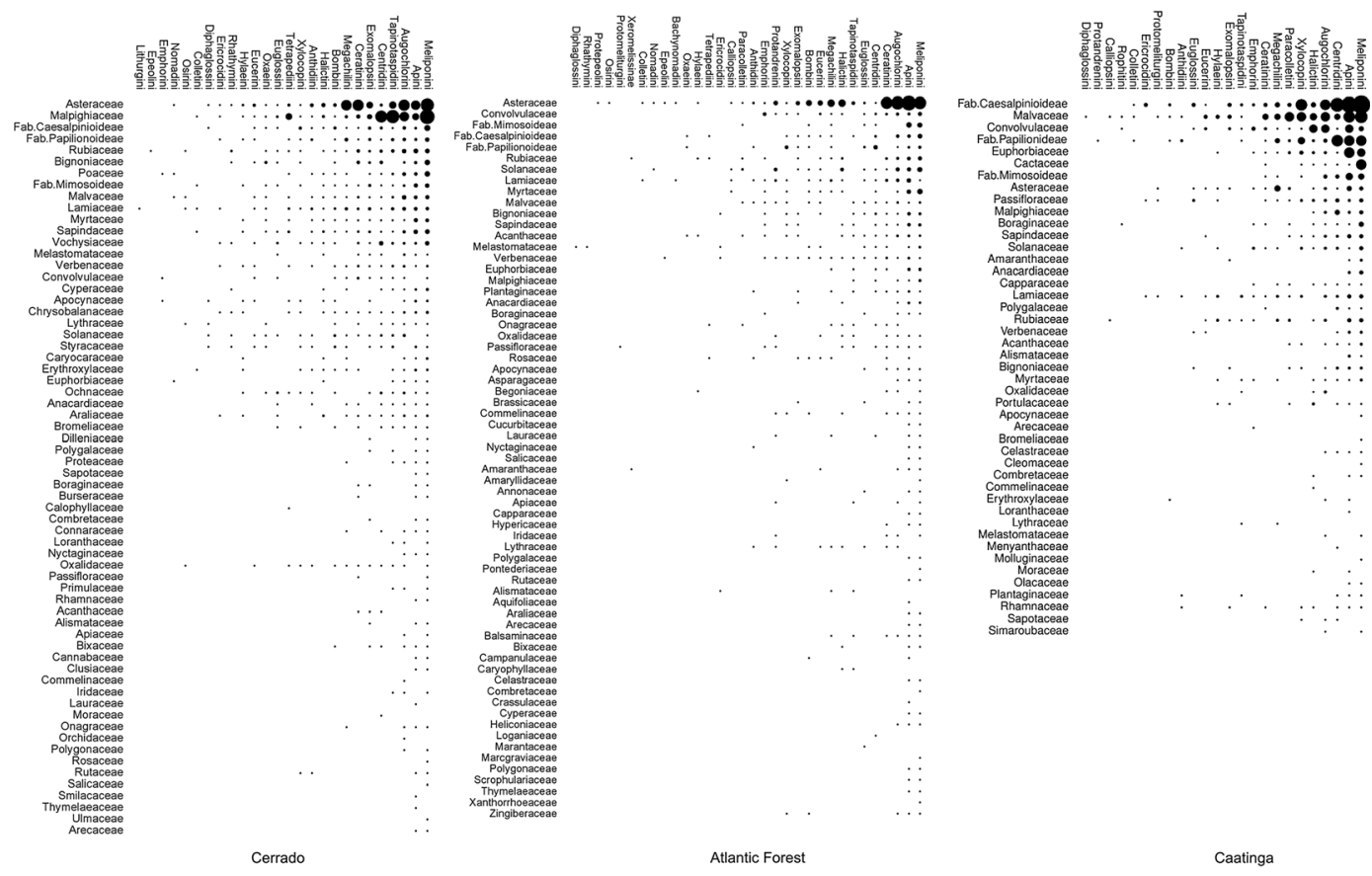

Figure 2. Importance of each plant family to the tribes of Apoidea in the three ecoregions of Brazil. The size of dots represents the proportion of species in a botanical family, which are visited by members of each tribe of bees compared with other botanical families. The botanical families are ordered from most to least rich in species (top to bottom). The tribes are ordered from most generalist to most specialist bees (right to left).

various floral species. Centridini, Augochlorini, and Ceratinini are tribes rich in species in Brazilian habitats (Aguiar 2003; Andena et al. 2012; Antonini and Martins 2003; Milet-Pinheiro and Schlindwein 2008) and they are formed by solitary and communal (in Augochlorini) bees. The great species richness increases the number of plant species explored by these tribes because the distinct species are active at different times of the year and, therefore, use different floral resources (Heithaus 1979). However, despite Megachilini is rich in species, there is reduced
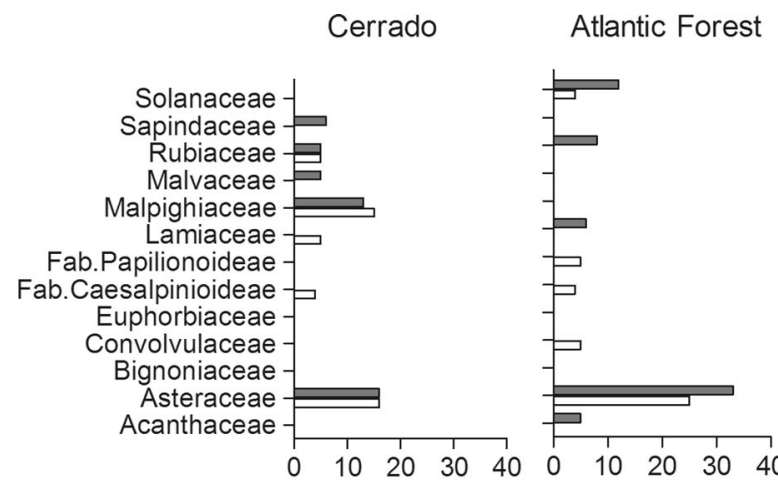

Caatinga

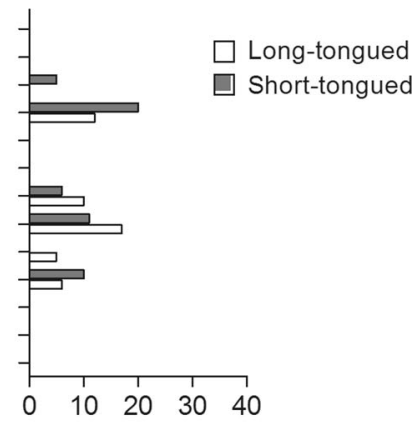

Percentage of species of plants visited (per botanical family)

Figure 3. Percentage relationship between the five most visited plant families by long- and short-tongued bees in each ecoregion. 
(a)

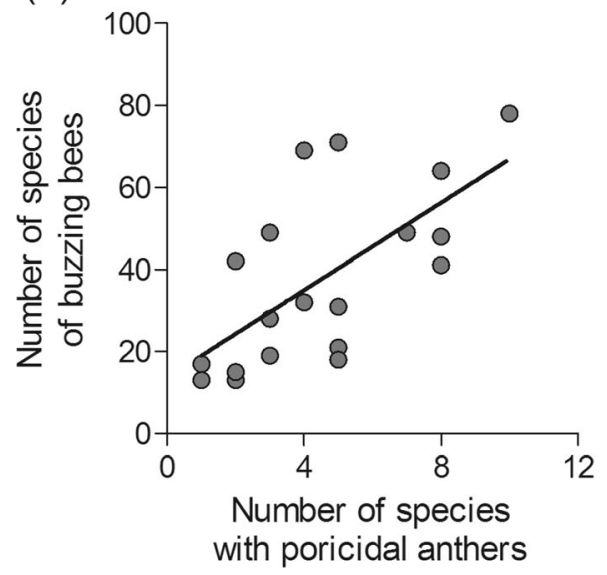

(c) (b)

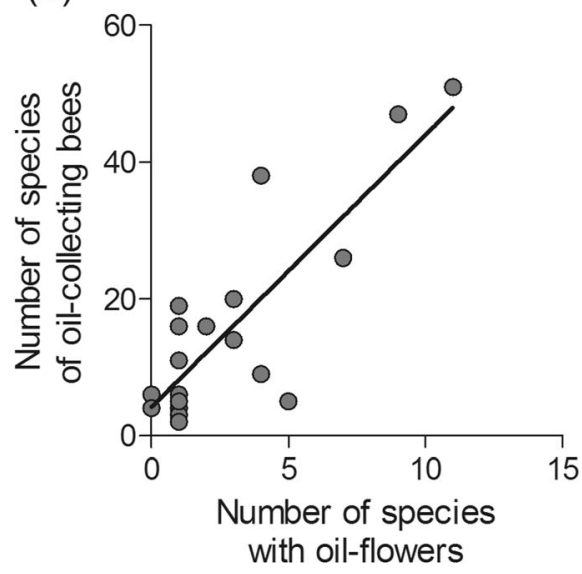

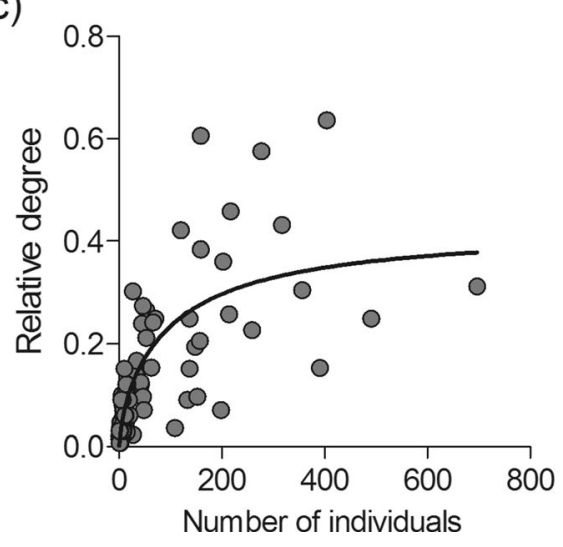

Figure 4. Relationship between specialist bees and their guild of associated plants $(\mathbf{a}, \mathbf{b})$ and relationship between population size and level of generalism of Meliponini bees (c). The relationship between the number of bees that collect pollen by vibration and the number of plants with poricidal anthers (a), and the relationship between the number of floral oil-collecting bees and the number of oil-flower plants (b). The regression curve of the data (c).

amplitude of floral resources used by this tribe because most of its members are oligolectic (Buschini et al. 2009; Schlindwein 2004a, b).

Some botanical families were regularly visited by oligolectic bees across the three ecoregions analyzed. Megachilini species have been associated with Asteraceae as a pollen source (Buschini et al. 2009; Schlindwein 1998, 2004b). The high representativeness of Asteraceae in the set of plants used by Megachilini in the Caatinga, where this family of plants has few species, suggests a preference for using resources of this family. The preferential use of Convolvulaceae by Emphorini, of Passifloraceae by Protomelithurgini, of Malvaceae by Paracolletini, and of Malvaceae and Asteraceae by
Eucerini found in our work have been also documented elsewhere (Pacheco Filho et al. 2011; Pick and Schlindwein 2011; Schlindwein 2004b). In general, these preferences suggest that these plant families are essential to the maintenance of the populations of these bees. Thus, the visitation to plants of a certain taxon should remain throughout different habitats, regardless of their abundance.

In general, long- and short-tongued bees have concentrated their visitations to the members of the most well-represented plant families (e.g., Malvaceae and Asteraceae). The richest botanical families are usually those with the highest number of individuals (Alcorado-Filho et al. 2003; Cavalcante et al. 2000). This greater abundance 
(a)

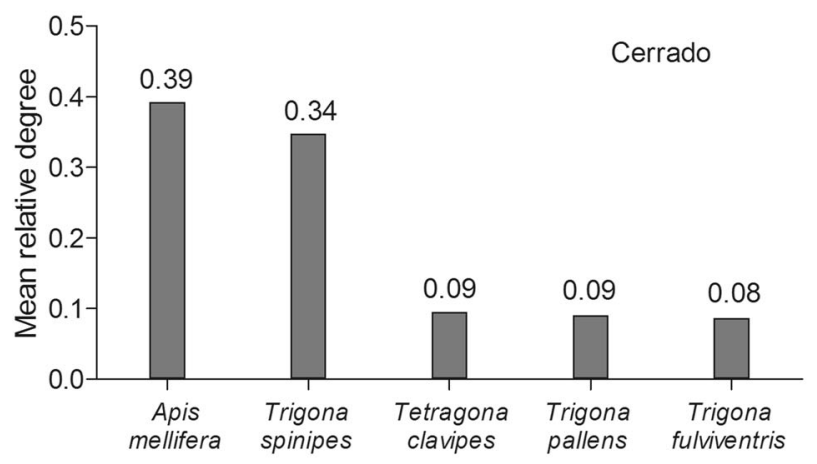

(c)

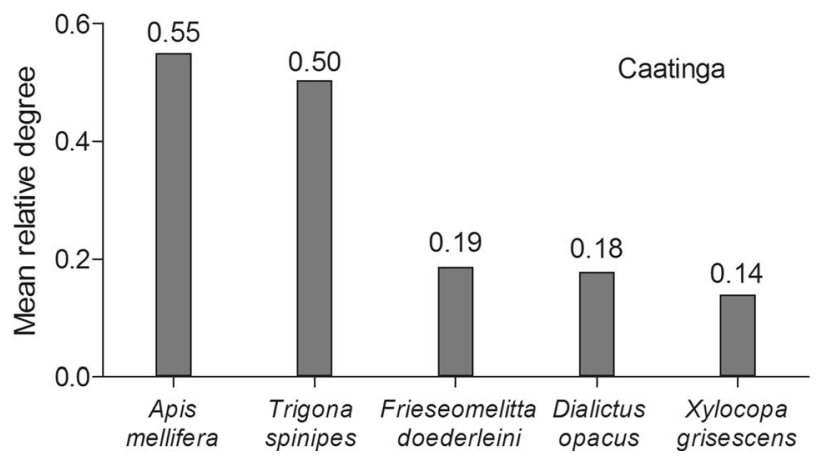

(b)

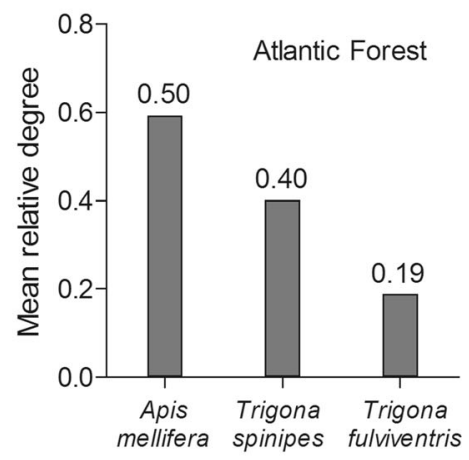

Figure 5. Species of more generalist bees (higher relative degree) of the ecoregion of a Cerrado, b Atlantic Forest, and c Caatinga.

should maximize the rate of encounter between the flowers of these families and the bee fauna, and hence, the pattern of interaction should result from random interactions proportional to species abundance (Stang et al. 2007; Vázquez 2005). As these plant families are composed mainly of plants with open flowers of easy access to nectar, this result also points out that long-tongued bees do not concentrate their search for nectar only in long-tube flowers.

The positive relationship between the richness of bees that collect pollen by vibration and the richness of plants with poricidal anthers suggests interdependence between these groups of plants and bees. Plants with poricidal anthers usually have pollen as the only floral attractant (De Luca and Vallejo-Marín 2013). As pollen collection by vibration is apparently not related to oligolecty (Schlindwein 2004a), this positive relationship should result from either the preferential search for sources of less disputed pollen (because it is less accessible) or from the possible greater efficiency in collecting pollen from poricidal anthers compared with other types of anthers.

Moreover, the relationship between oil-flower plants and oil-collecting bees remains over the geographic space, and the greatest diversity of floral oil sources (notably Malpighiaceae) is related to the higher richness of oil-collecting bees. Malpighiaceae is recognized as the most important and numerous floral source of oil; it is important for the provision of oil-collecting bee larvae (Alvesdos-Santos et al. 2007). On the other hand, these bees are responsible for pollination of several plant species (with and without oil-flowers) of natural and farming environments (Frankie et al. 2004; Freitas and Paxton 1998; Magalhães and Freitas 2013; Sazan et al. 2014). Thereby, we can infer that the maintenance of these plants providing floral oil is essential both to the maintenance of the populations and diversity of oil-collecting bees, as shown by Rosa and Ramalho (2011), and for the maintenance of other plants dependent on these bees. 
A. mellifera is the most generalist bee of the ecoregions studied. It is commonly used in the pollination of many crops (Garibaldi et al. 2013) and has been considered a pollinator of native species, even where it is invasive (Freitas and Paxton 1998; Osorio-Beristain et al. 1997). For this reason, researchers have suggested that in the absence of native pollinators, A. mellifera can assume their functions and reduce the loss caused by the scarcity of pollinators (Xia et al. 2007). However, its effectiveness has been questioned as a pollinator (Ollerton et al., 2012; Westerkamp 1991), and strong evidence suggests that it impairs the populations of pollinators and native plants, affecting their interactions (Goulson and Sparrow 2008; Hansen et al. 2002).

Species of stingless bees (mainly $T$. spinipes ) were the most generalist native bees in the use of floral resources. They commonly interact with plants of the botanical families best represented in Neotropical environments (Lima-Verde et al. 2014; Ramalho et al. 1990, in this study). This plastic and opportunistic trophic behavior does not appear to represent a species-specific characteristic, but a response to the local abundance of these bees, as observed herein. The large number of workers favors the level of dispersion of these bees in the field, contributing to the location of alternative flower sources and increasing the level of generalism (Cortopassi-Laurino and Ramalho 1988; Kleinert et al. 2012).

$X$. grisescens was the only parasocial species, and $D$. opacus , the only non-Apidae species among the most generalist. $X$. grisescens is a large-sized bee species responsible for the reproduction of many species of the native flora and tropical crops of high economic value (Junqueira et al. 2012; Neves et al. 2011). As for D. opacus, little is known about its importance to the native or cultivated flora. In the meantime, recent studies have shown that generalist species are responsible for maintaining the cohesion of bee-plant networks and for the persistence of communities (Memmott et al. 2004).

On the basis of raw data, we demonstrated that some groups of bees have close relationships with certain botanical families, such that the diversity of some plant groups (e.g., oil-flower plants and plants with poricidal anthers) was directly related to the diversity of some functional groups of bees (e.g., bees that collect oil or bees that vibrate). In this sense, we infer that the maintenance of populations of a given botanical family is important for the conservation of populations of bees associated and vice versa. Although generalist bees are important for the maintenance of beeplant interaction networks (Memmott et al. 2004), it is unlikely that they can successfully replace the specialist bees, given the greater pollination effectiveness of the latter (Schlindwein 2004a, b). Therefore, we believe that specialist bees are irreplaceable pollinators in Neotropical forests.

\section{ACKNOWLEDGMENTS}

We are grateful to the researchers who made available their data in theses and articles, especially to Camila Magalhães Pigozzo for her kindness in directly furnishing her data. We thank Cláudia Inês da Silva, Isabel Alves dos Santos, and two anonymous reviewers who greatly contributed with suggestions and comments to the final version of this paper, Brazilian National Council for Scientific and Technological Development (CNPq), Brasília-Brazil, for financial support for this research (Project no. 476794/2011-0) and for research grant to B.M.F. (Proc. no.302934/2010-3).

Association abeille -fleur en région néotropicale : implications sur la conservation des abeilles et la pollinisation des plantes

Spécialisation / abeilles généralistes / forêt atlantique / caatinga / cerrado

Bienen-Blüten -Assoziationen in den Neotropen : Bedeutungen für den Erhalt der Bienen und die Pflanzenbestäubung

Spezialisierung / Generalisten / Atlantischer Regenwald / Caatinga Trockenwald / Cerrado

\section{REFERENCES}

Aguiar, C.M.L. (2003) Utilização de recursos florais por abelhas (Hymenoptera, Apoidea) área uma área de Caatinga (Itatim, Bahia, Brasil). Rev. Bras. Zool 20 (1997), 457-467

Alcorado-Filho, F.G., Sampaio, E.V.S.B., Rodal, M.J.N. (2003) Florística e fitossociologia de um remanescente de vegetação caducifólia espinhosa arbórea em Caruaru, Pernambuco. Acta. Bot. Bras 17 (2), 287-303 
Alves-dos-Santos, I., Machado, I.C., Gaglianone, M.C. (2007) História natural das abelhas coletoras de óleo. Oecologia Bras 11 (4), 544-557

Andena, S.R., Santos, E.F., Noll, F.B. (2012) Taxonomic diversity, niche width and similarity in the use of plant resources by bees (Hymenoptera: Anthophila) in a cerrado area. J. Nat. Hist 46(27-28), 1663-1687

Antonini, Y., Martins, R.P. (2003) The flowering-visiting bees at the ecological station of the Universidade Federal de Minas Gerais, Belo Horizonte, MG. Braz. Neotropical. Entomol 32 (4), 565-575

Bascompte, J., Jordano, P., Olesen, J. (2006) Asymmetric coevolutionary networks facilitate biodiversity maintenance. Science 312 (5772), 431-433

Brasil. (2012) Manual Técnico da Vegetação Brasileira. Instituto Brasileiro de Geografia e Estatística - IBGE, Rio de Janeiro

WWF Brazil (2014) Mata Atlântica [online] http:// www.wwf.org.br/natureza_brasileira/areas_prioritarias/ mata_atlantica/ (accessed on 05 January 2014)

Buschini, M.L.T., Rigon, J., Cordeiro, J. (2009) Plants used by Megachile (Moureapis) sp. (Hymenoptera: Megachilidae) in the provisioning of their nests. Braz. J Biol 69 (4), 1187-1194

Cardinal, S., Danforth, B.N. (2013) Bees diversified in the age of eudicots. Proc. R. Soc. B 280 (1755), 1-9

Carvalho, A.T., Schlindwein, C. (2011) Obligate association of an oligolectic bee and a seasonal aquatic herb in semi-arid north-eastern Brazil. Biol. J. Linn. Soc 102 (2), 355-368

Cavalcante, A., Soares, J.J., Figueiredo, M.A. (2000) Comparative phytosociology of tree sinusiae between contiguous forests in different stages of succession. Rev. Bras. Biol 60 (4), 551-562

Cortopassi-Laurino, M., Ramalho, M. (1988) Pollen harvest by africanized Apis mellifera and Trigona spinipes in São Paulo: botanical and ecological views. Apidologie 19(1), 1-24

De Luca, P.A., Vallejo-Marín, M. (2013) What's the "buzz" about? The ecology and evolutionary significance of buzz-pollination. Curr. Opin. Plant Biol 16 (4), 429-435

Faegri, K., van der Pijl, L. (1979) The principles of pollination ecology. Pergamon Press, Oxford

Fenster, C.B., Armbruster, W.S., Wilson, P., Dudash, M.R., Thomson, J.D. (2004) Pollination syndromes and floral specialization. Annu. Rev. Ecol. Evol. Syst 35(1), 375-403

Frankie, G.W., Haber, W.A., Vinson, S.B., Bawa, K.S., Ronchi, P.S., Zamora, N. (2004) Flowering phenology and pollination systems diversity in the dry forest. In: Frankie, G.W., Mata, A., Vinson, S.B. (eds.) Biodiversity conservation in Costa Rica: Learning the lessons in a seasonal dry forest, pp. 17-29. University of California Press, Berkeley

Freitas, B.M., Paxton, R.J. (1998) A comparison of two pollinators: The introduced honey bee Apis mellifera and an indigenous bee Centris tarsata on cashew Anacardium occidentale in its native range of $\mathrm{NE}$ Brazil. J. Appl. Ecol 35(1), 109-121
Freitas, B.M., Imperatriz-Fonseca, V.L., Medina, L.M., Kleinert, A.D.M.P., Galetto, L., Nates-Parra, G., Quezada-Euán, J.J.G. (2009) Diversity, threats and conservation of native bees in the Neotropics. Apidologie 40 (3), 332-346

Garibaldi, L.A., Steffan-Dewenter, I., Winfree, R., Aizen, M.A., Bommarco, R., et al. (2013) Wild pollinators enhance fruit set of crops regardless of honey bee abundance. Science 339 (6127), 1608-1611

Goulson, D., Sparrow, K.R. (2008) Evidence for competition between honeybees and bumblebees; effects on bumblebee worker size. J. Insect Conserv 13 (2), 177-181

Hansen, D.M., Olesen, J.M., Jones, C.G. (2002) Trees, birds and bees in Mauritius: exploitative competition between introduced honey bees and endemic nectarivorous birds? J. Biogeogr 29 (5-6), 721-734

Heithaus, E.R. (1979) Community structure of neotropical flower visiting bees and wasps: diversity and phenology. Ecology 60 (1), 190-202

Junqueira, C.N., Hogendoorn, K., Augusto, S.C. (2012) The use of trap-nests to manage carpenter bees (Hymenoptera: Apidae: Xylocopini), pollinators of passion fruit (Passifloraceae: Passiflora edulis cf. flavicarpa). Ann. Entomol. Soc Am 105(6), 884-889

Kleinert, A.M.P., Ramalho, M., Cortopassi-Laurino, M., Ribeiro, M.F., Imperatriz-Fonseca, V.L. (2012) Social bees (Bombini, Apini, Meliponini). In: Panizzi, A.R., Parra, J.R.P. (eds.) Insect Bioecology and Nutrition for Integrated Pest Management, pp. 237-271. Embrapa, Brasília

Lima-Verde, L.W., Loiola, M.I., Freitas, B.M. (2014) Angiosperm flora used by meliponine guilds (Apidae, Meliponina) occurring at rainforest edges in the state of Ceará. Braz. An. Acad. Bras. Ciênc . doi:10.1590/ 0001-3765201420130067

Magalhães, C.B., Freitas, B.M. (2013) Introducing nests of the oil-collecting bee Centris analis (Hymenoptera: Apidae: Centridini) for pollination of acerola (Malpighia emarginata ) increases yield. Apidologie 44 (2), 234-239

Memmott, J., Waser, N.M., Price, M.V. (2004) Tolerance of pollination networks to species extinctions. Proc. Biol. Sci 271 (1557), 2605-2611

Michener, D.C. (2007) The bees of the world. The Johns Hopkins University Press, Baltimore

Milet-Pinheiro, P., Schlindwein, C. (2008) Comunidade de abelhas (Hymenoptera, Apoidea) e plantas em uma área do Agreste pernambucano. Bras. Rev. Bras. Entomol 52 (4), 625-636

Müller, A. (1996) Host plant specialization in the western palearctic anthidiine bees (Hymenoptera: Apoidea: Megachilidae). Ecol. Monogr 66 (2), 235-257

Neves, E.L., Machado, I.C., Viana, B.F. (2011) Sistemas de polinização e de reprodução de três espécies de Jatropha (Euphorbiaceae) na Caatinga, semi-árido do Brasil. Rev. Bras. Bot. 34 (4), 553-563

Oliveira-Filho, A.T., Fontes, M.A.L. (2000) Patterns of floristic differentiation among Atlantic Forests in southeastern Brazil and the influence of climate. Biotropica 32 (4b), 793-810 
Oliveira-Filho, A.T., Ratter, J.A. (2002) Vegetation physiognomies and woody flora of the cerrado biome. In: Oliveira, P.S., Marquis, R.J. (eds.) The cerrados of Brazil ecology and natural history of a neotropical savanna, pp. 91-120. Columbia University Press, New York

Ollerton, J., Price, V., Armbruster, W.S., Memmott, J., Watts, S., et al. (2012) Overplaying the role of honey bees as pollinators: A comment on Aebi and Neumann. Trends Ecol. Evol 27 (3), 141-142

Olson, D.M., Dinerstein, E., Wikramanayake, E.D., Burgess, N.D., Powell, G.V.N., et al. (2001) Terrestrial ecoregions of the World: A new map of life on Earth. Bioscience 51 (11), 933-938

Osorio-Beristain, M., Dominguez, C.A., Eguiarte, L.E., Benrey, B. (1997) Pollination efficiency of native and invading Africanized bees in the tropical dry forest annual plant, Kallstroemia grandiflora Tors ex Gray. Apidologie 28(1), 11-16

Pacheco Filho, A.J.S., Westerkamp, C., Freitas, B.M. (2011) Ipomea bahiensis pollinators: Bees or butterflies? Flora 206 (7), 662-667

Patiny, S., Michez, D., Danforth, B.N. (2008) Phylogenetic relationships and host-plant evolution within the basal clade of Halictidae (Hymenoptera, Apoidea). Cladistics 24 (3), 255-269

Pick, R.A., Schlindwein, C. (2011) Pollen partitioning of three species of Convolvulaceae among oligolectic bees in the Caatinga of Brazil. Plant Syst. Evol 293 (1-4), 147-159

Pinheiro-Machado, C., Santos, I.A., Imperatriz-Fonseca, V.L., Kleinert, A.M.P., Silveira, F.A. (2002) Brazilian bee surveys: State of knowledge, conservation and sustainable use. In: Kevan, P., Imperatriz-Fonseca, V.L. (eds.) Pollinating bees - The conservation link between agriculture and nature, pp. 115-129. Ministry of Environment, Brasília

Prado, D.E. (2003) As caatingas da América do Sul. In: Leal, I.R., Tabarelli, M., da Silva, J.M.C. (eds.) Ecologia e conservação da Caatinga, pp. 3-7. Editora Universitária da UFPE, Recife

Ramalho, M., Kleinert-Giovannini, A., ImperatrizFonseca, V.L. (1990) Important bee plants for stingless bees (Melipona and Trigonini) and Africanized honeybees (Apis mellifera) in neotropical habitats: a review. Apidologie 21 (5), 469-488

Rizzini, C.T. (1997) Tratado de Fitogeografia do Brasil: aspectos ecológicos, sociológicos e florísticos. Âmbito Cultural Edições Ltda, Rio de Janeiro
Robertson, C. (1925) Heterotropic bees. Ecology 6(4), 412-436

Rosa, J.F., Ramalho, M. (2011) The spatial dynamics of diversity in Centridini bees: the abundance of oilproducing flowers as a measure of habitat quality. Apidologie 42 (5), 669-678

Sakagami, S.F., Laroca, S., Moure, J.S. (1967) Wild bees biocenotics in São José dos Pinhais (PR), South Brazil - preliminary report. J. Fac. Sci. Hokkaido Univ. Ser. VI Zool 19 (2), 253-291

Sazan, M.S., Bezerra, A.D.M., Freitas, B.M. (2014) Oil collecting bees and Byrsonima cydoniifolia A. Juss. (Malpighiaceae) interactions: the prevalence of longdistance cross pollination driving reproductive success. An. Acad. Bras. Cienc 86(1), 347-358

Schlindwein, C. (1998) Frequent oligolecity characterizing a diverse bee-plant community in a xerophytic bushland of subtropical Brazil. Stud. Neotrop. Fauna Environ 33(1), 46-59

Schlindwein, C. (2004a) Abelhas Solitárias e Flores: Especialistas são Polinizadores Efetivos? In: 55 Congresso Nacional de Botânica. 26 Encontro Regional de Botânicos de MG, BA, ES, Viçosa, MG. Sociedade Botânica do Brasil. p. 1-8

Schlindwein, C. (2004b) Are oligolectic bees always the most effective pollinators? In: Freitas, B.M., Pereira, J.O.P. (eds.) Solitary Bees Conservation, Rearing and Management for Pollination, pp. 231-240. Federal University of Ceará, Fortaleza

Spivak, M., Mader, E., Vaughan, M., Euliss, N.H. (2011) The plight of the bees. Environ. Sci. Technol 45 (1), 34-38

Stang, M., Klinkhamer, P.G.L., van der Meijden, E.D.A. (2007) Asymmetric specialization and extinction risk in plant-flower visitor webs: a matter of morphology or abundance? Oecologia 151 (3), 442-453

Vázquez, D.P. (2005) Degree distribution in plant-animal mutualistic networks: forbidden links or random interactions? Oikos $\mathbf{1 0 8}(2), 421-426$

Waser, N., Chittka, L., Price, M., Williams, N., Ollerton, J. (1996) Generalization in pollination systems, and why it matters. Ecology 77 (4), 1043-1060

Westerkamp, C. (1991) Honeybees are poor pollinatorswhy? Plant Syst Evol 177 (1-2), 71-75

Xia, J., Sun, S.G., Guo, Y.H. (2007) Honeybees enhance reproduction without affecting the outcrossing rate in endemic Pedicularis densispica (Orobanchaceae). Plant Biol 9(6), 713-719 